\title{
PENGARUH BUDAYA ORGANISASI TERHADAP KINERJA KARYAWAN PADA BANK BJB SYARIAH KCP CIAWI TASIKMALAYA
}

\author{
Faisal $^{1}$, Muhamad Dani Somantri ${ }^{2}$, Nurul Hidayatun Napsiah ${ }^{3}$ \\ ${ }^{1}$ Fakultas Syariah, Institut Agama Islam Latifah Mubarokiyah Tasikmalaya, Indonesia \\ faisaltanto123@gmail.com \\ ${ }^{2}$ Fakultas Syariah, Institut Agama Islam Latifah Mubarokiyah Tasikmalaya, Indonesia \\ muhamaddanisomantri34@gmail.com \\ ${ }^{3}$ Fakultas Syariah, Institut Agama Islam Latifah Mubarokiyah Tasikmalaya, Indonesia \\ nurulhidayatunafsiah@gmail.com
}

\begin{abstract}
Each organization has a distinct characteristic. This difference is the identity of the organization that is then called the organizational culture. Organizational culture refers to the unique relationship of norms, values, beliefs and behavioral ways that characterize how groups and individuals get things done. Cultural relationships with how to make a commitment to realizing the vision, winning the hearts of customers, winning competitors, and building the strength of the company. The purpose of this research is to know the influence of organizational culture towards employee performance and how much the percentage of organizational culture influences the employee's performance. This research uses a quantitative approach, done by collecting data of numbers. Data is then processed and analyzed to obtain scientific information. Data obtained by the survey results to 17 respondents as a data collection tool. The study used a survey method with simple linear regression data analysis techniques and Pearson's correlation to know the magnitude of the correlation between the $X$ variables to the $Y$ variables, as well as conducting hypotheses to figure out the magnitude of each variable's influence. Once analyzed using a correlation test there is a relationship between the influence of organizational culture to performance with a correlation value of 0.939. As well as an influence between independent variables (organizational cultures) on dependent variables (employee performance) of a simple linear regression test result obtained a significant value less than $\alpha(0.000<0.025)$. From the coefficient of determination of the obtained value of $R 20.883$, from the value of coefficient of determination can be concluded that the employee's performance influenced by the organizational culture of $88.3 \%$.
\end{abstract}

Keyword: organizational culture, employee performance 


\begin{abstract}
ABSTRAK
Setiap organisasi mempunyai ciri khas yang berbeda. Perbedaan inilah yang menjadi identitas bagi organisasi yang kemudian dinamakan budaya organisasi. Budaya organisasi mengacu pada hubungan yang unik dari norma-norma, nilai-nilai, kepercayaan dan cara berprilaku yang menjadi ciri bagaimana kelompok dan individu dalam menyelesaikan sesuatu. Budaya hubungan dengan bagaimana membuat komitmen untuk mewujudkan visi, memenangkan hati pelanggan, memenangkan pesaing, dan membangun kekuatan perusahaan.Tujuan dari penelitian ini adalah untuk mengetahui pengaruh budaya organisasi terhadap kinerja karyawan dan seberapa besar presentase pengaruh budaya organisasi terhadap kinerja karyawan. Penelitian ini menggunakan pendekatan kuantitatif, dilakukan dengan mengumpulkan data yang berupa angka. Data kemudian diolah dan dianalisis untuk mendapatkan suatu informasi ilmiah. Data diperoleh hasil penyebaran kuesioner kepada 17 responden sebagai alat pengumpul data. Penelitian ini menggunakan metode survey dengan teknik analisis data regresi linear sederhana dan korelasi Pearson untuk mengetahui besarnya korelasi antara variabel X terhadap Variabel Y, serta melakukan uji hipotesis untuk mengetahui besarnya pengaruh masing-masing variabel.Setelah dianalisis dengan menggunakan uji korelasi terdapat hubungan antara pengaruh budaya organisasi terhadap kinerja dengan nilai korelasi 0,939. Serta terdapat pengaruh antara variabel independen (budaya organisasi) terhadap variabel dependen (kinerja karyawan) dari hasil uji regresi linear sederhana didapatkan nilai signifikan lebih kecil dari $\alpha(0,000<0,025)$. Dari uji Koefisien determinasi didapatkan nilai $R^{2} 0,883$, dari nilai koefisien determinasi dapat disimpulkan bahwa kinerja karyawan dipengaruhi budaya organisasi sebesar 88,3\%.
\end{abstract}

Kata Kunci: budaya organisasi, kinerja karyawan 


\section{PENDAHULUAN}

Budaya organisasi telah lama dikenal oleh umat manusia, namun manusia belum menyadari bahwa suatu keberhasilan kerja itu berakar dari nilai-nilai yang dimiliki dan prilaku yang menjadi kebiasaanya. Nilai-nilai tersebut berawal dari kebiasaan, norma, dan kaidah yang menjadi keyakinannya dan menjadi suatu kebiasaan dalam prilaku suatu organisasi (Lidiawati, 2008, p. 1). Budaya organisasi yang kuat akan membantu perusahaan dalam memberikan kepastian kepada seluruh karyawan untuk berkembang bersama, tumbuh dan berkembangnya perusahaan.budaya organisasi memiliki tujuan untuk mengubah sikap dan prilaku SDM (Handoko, 2008, p. 15).

Budaya organisasi memiliki peranan penting dalam mencapai tujuan organisasi. Budaya organisasi berperan penting dalam pencapaian suatu tujuan organisasi karena budaya organisasi merupakan suatu cara kerja yang bermutu dan didasari oleh nilai yang penuh makna, dan memberikan motivasi serta inspirasi untuk bekerja lebih baik.dengan adanya budaya organisasi juga dapat mengubah sikap dan prilaku individu untuk mencapai suatu produktivitas kerja. Menurut Barkow dalam penelitiannya menyebutkan bahwa faktor kemampuan beradaptasi, faktor integrasi sosial, faktor moral serta faktor persepsi terhadap kerja merupakan faktor-faktor yang mempengaruhi budaya organisasi. Jika faktor-faktor tersebut lebih diperhatikan lebih baik lagi akan dapat menumbuhkan kinerja karyawan untuk bekerja lebih keras guna membantu keberhasilan perusahaan(Lidiawati, 2008, p. 2).

Dunia perbankan juga tak ingin ketinggalan dalam euforia budaya organisasi. Untuk mempertahankan eksistensinya bank dituntut untuk memiliki visi dan misi yang jelas dan strategis, dan setiap komponen didalamnya juga dituntut untuk dapat merealisasikan visi dan misi perusahaan. Visi dan misi inilah yang kemudian melahirkan nilai-nilai yang diyakini oleh anggota organisasi dan mencerminkan budaya organisasi(Nurjanah, 2008, p. 22). Maka, untuk mencapai profesionalisme kerja. Manajemen puncak dan divisi sumber daya manusia dituntut untuk menciptakan budaya organisasi yang berkualitas melalui penerapan sistem manajemen yang baik. Tentunya semua ini dilakukan tidak hanya untuk perbaikan budaya organisasi tetapi juga dalam rangka menciptakan knowledge worker, yaitu karyawan yang selalu ingin memperbaiki diri dengan terus belajar untuk meningkatkan potensi yang dimilikinya. Dengan didukung para knowledge worker, bukan hanya kinerja karyawan yang meningkat tetapi prestasi keuangan bank meningkat (Nurjanah, 2008, p. 16). Hal ini dapat dilihat dari peningkatan funding, financing dan pertumbuhan aset bank syariah di Indonesia sebagai berikut: 
Tabel 1.1

Perkembangan Funding, Financing dan Total Aset Bank Syariah:

\begin{tabular}{|c|c|c|c|}
\hline Tahun & Funding & Financing & Total aset \\
\hline 2014 & $36,18 \%$ & $40,77 \%$ & $38,77 \%$ \\
\hline 2015 & $36,20 \%$ & $43,90 \%$ & $39,00 \%$ \\
\hline 2016 & $40,80 \%$ & $45,96 \%$ & $42,80 \%$ \\
\hline
\end{tabular}

Sumber: Statistik OJK (Juni 2016)

Dilihat dari tabel di atas perbankan syariah di Indonesia sampai Juni 2016 prestasi keuangannya membaik yaitu tingginya tingkat pertumbuhan funding financing dan total aset. Inisiatif, pengarahan, dan pola komunikasi adalah atribut budaya organisasi yang kuat. Budaya pada tingkat ini adalah driver nyata untuk kinerja karyawan yang unggul dan sumber pasti keunggulan kompetitif yang sangat sulit bagi pesaing untuk meniru. Perubahan membawa dampak pada perubahan budaya organisasi yang mau tidak mau harus menghadapi serangkaian adaptasi. Pengelolaan dan penggunaan keuangan sendiri harus cukup memadai untuk pembiayaan penyelenggaraan pemerintah dan pembangunan daerah. Demikian pula, dengan budaya organisasi yang ada perlu diperbaiki sehingga diharapkan dapat menigkatkan kinerja (Abdurrahman, 2013, p. 41). Dalam menjalankan sebuah organisasi tidak terlepas dari kontribusi dari karyawan. Sebagaimana dikemukakan Maltis dan Jackson bahwa sumber daya manusia pada era sekarang ini semakin besar peranannya dalam mencapai sukses organisasi (Abdurrahman, 2013, p. 40).

Menurut Sedarmayanti kinerja karyawan sebagai salah satu faktor penerapan dari budaya organiasi. Budaya organisasi ini dibuat agar karyawan memiliki kemampuan untuk memiliki proses perencanaan, pelaksanaan, pengontrolan, dan perbaikan secara terus menerus yang mampu membuat kinerja perusahaan meningkat. Karyawan yang mampu mengaplikasikan budaya organisasi akan memiliki mental yang kuat untuk menjadi yang terbaik layaknya seorang juara, dengan selalu berfikir positif dan cerdik dalam kegiatan sehari-hari (Abdurrahman, 2013, p. 41). Perkembangan perbankan syariah dari tahun ke tahun semakin meningkat, lembaga keuangan syariah yang dibentuk sejak tiga dekade terakhir sebagai alternatif bagi lembaga keuangan konvensional, terutama ditujukan menawarkan kesempatan investasi, pembiayaan dan peniagaan yang sesuai dengan prinsip-prinsip syariah. Berikut ini tabel perkembangan bank syariah di Indonesia: 
Tabel 1.2

Perkembangan Perbankan Syariah

\begin{tabular}{|c|c|c|c|c|c|c|c|}
\hline \multirow{2}{*}{$\begin{array}{c}\text { Kelompok } \\
\text { Bank }\end{array}$} & \multicolumn{7}{|c|}{ Tahun } \\
\cline { 2 - 8 } & $\mathbf{2 0 1 0}$ & $\mathbf{2 0 1 1}$ & $\mathbf{2 0 1 2}$ & $\mathbf{2 0 1 3}$ & $\mathbf{2 0 1 4}$ & $\mathbf{2 0 1 5}$ & $\mathbf{2 0 1 6}$ \\
\hline BUS & 11 & 11 & 11 & 11 & 12 & 12 & 13 \\
\hline UUS & 23 & 24 & 24 & 23 & 22 & 21 & 20 \\
\hline BPRS & 150 & 155 & 158 & 163 & 163 & 163 & 166 \\
\hline
\end{tabular}

Sumber: Statistik Perbankan Syariah (2016)

Eksistensi perbankan syariah di Indonesia saat ini semakin meningkat sejak adanya Undang-Undang No. 21 Tahun 2008 Tentang Perbankan Syariah yang memberikan landasan operasi yang lebih jelas bagi bank syariah. Sehingga berdasarkan Tabel 1.2 pada tahun 2016 jumlah Bank Umum Syariah (BUS) di Indonesia yang beroperasi menjadi 13, diikuti oleh 20 Unit Usaha Syariah (UUS), dan 166 Bank Pembiayaan rakyat Syariah (BPRS).

Bank BJB Syariah merupakan salah satu bank umum syariah di Indonesia yang berbasis syariah di mana hukum yang melandasi segala proses aktivitas terjadi di bank kesemuanya itu berdasarkan hukum Al-Quran dan As-sunah. Perkembangan Bank BJB Syariah semakin meningkat ini dibuktikan dengan, peningkatan yang signifikan dari masyarakat yang percaya untuk menjadi nasabahnya baik dalam hal pendanaan maupun pembiayaan. Berarti dengan demikian respn masyarakat terhadap Bank BJB Syariah semakin meningkat.

Bank BJB Syariah yang telah memiliki dan menerapkan budaya perusahaan. Budaya perusahaan bagian dari upaya mengubah mindset karyawan. Penguatan budaya perusahan dinilai penting sebelum melakukan eksplorasi bisnis. Persaingan bisnis di dunia perbankan syariah cukup ketat. Persaingan akan semakin ketat sat bergulir pasar bebas di asia tenggara yang akan bergulir pada tahun 2020 untuk perbankan. Bank BJB Syariah harus mempersiapkan pondasi yang kuat agar dapat bersaing.

Pada tahun 2014 Bank BJB Syariah mengembangkan suatu budaya organisasi baru yang disebut Maslahah (Militan, Amanah, Solusi, Layanan, Harmoni dan Holistik). Maslahah dipilih karena menjadi ikon Bank BJB Syariah. Terminologi ini semakin kuat melalui budaya perusahaan. Maslahah diharapkan dapat menjadi budaya perusahaan yang akan berimbas pada kinerja karyawan. Semua karyawan Bank BJB Syariah harus dapat memahami dengan benar budaya perusahaanya, karena pemahaman ini berkaitan dengan setiap langkah ataupun kegiatan yang dilakukan, baik perencanaan yang bersifat strategis maupun taktikal ("Tahun 2014 Bank BJB Syariah mengembangkan suatu budaya organisasi baru yang disebut Maslahah," n.d.).

Untuk mengukur efektifitas budaya perusahaan, Bank BJB Syariah akan rutin melakukan evaluasi. Evaluasi dilakukan setiap dua minggu sekali. Bank BJB Syariah juga 
memiliki seorang change agent disetiap kantor cabang dan change laeder yang berposisi sebagai kepala divisi, kepala cabang, dan pimpinan grup. Para agen akan memberikan contoh lain kepada karyawan lain.Hal ini seiring dengan penerapan sistem top down dimana penerapan budaya perusahaan dilakukan mulai dari jajaran direksi dan komisaris. Terdapat beberapa hambatan dalam pelaksanaan budaya maslahah khususnya di Bank BJB Syariah KCP Ciawi bank yang beroperasi sejak 13 januari 2013, telah menerapkan budaya maslahah tetapi masih mempunyai hambatan yaitu susahnya mengubah mind set pegawai lama yang sudah merasa nyaman dengan nilai dan prilaku yang sudah ada sebelumnya. Selain itu untuk menerapkan perilaku yang konsisten kareana nilai-nilai hidup seseorang sering kali tidak konsisten dan sangat dipengaruhi oleh kondisi psikis.

Menurut salah satu staf Bank BJB Syariah KCP Ciawi bahwa di Bank BJB Syariah tersebut sedang mengalami penurunan dalam hal pelayanan satu tahun terakhir dibuktikan dengan tabel sebagai berikut:

Tabel 1.3

Prestasi yang diperoleh Bank BJB Syariah KCP Ciawi

\begin{tabular}{|c|l|}
\hline Tahun & $\begin{array}{c}\text { Prestasi yang di Peroleh Bank BJB Syariah KCP } \\
\text { Ciawi }\end{array}$ \\
\hline 2015 & Juara 5 pelayanan seperiangan timur \\
\hline 2016 & Juara 1 pelayanan seperiangan timur \\
\hline 2017 & $\begin{array}{l}\text { Juara 2 jemput maslahah Se-kabupaten } \\
\text { Juara 3 olimpiade ke bank sentralan seperiangan timur }\end{array}$ \\
\hline \multicolumn{2}{|c|}{ Sumber : hasil wawancara di BJBS KCP Ciawi }
\end{tabular}

Dari tabel diatas dapat dilihat bahwa Bank Jabar Banten Syariah KCP Ciawi pada Tahun 2017 mengalami penurunan dalan hal pelayanan yaitu tidak termasuk juara 5 besar seperingan timur.Selain itu, fenomena yang terjadi pada bank BJB Syariah KCP Ciawi adalah menurunnya kinerja karyawan yang terlihat dari penurunan kinerja perusahaan. Masalah tersebut diduga karena pelaksanaan budaya organisasi dalam hal ini pengimplementasian nilai-nilai yang belum optimal, hal tersebut terlihat dari masih kurangnya rasa disiplin pegawai, kurang pedulinya dalam merawat barang-barang perusahaan, selain itu kurangnya kerja sama antar sesama pegawai menjadi masalah juga bagi perusahaan (Irfan, 2018). Atas dasar temuan masalah dalam pendahuluan, tertarik untuk meneliti budaya organisasi yang diterapkan pada Bank Jabar Banten Syariah KCP Ciawi Tasikmalaya.

\section{LITERATUR REVIEW \\ Pengertian Budaya}


Budaya atau kebudayaan berasal dari bahasa bahasa sanksekerta yaitu buddhayah, yang merupakan bentuk jamak dari buddhi (budhi dan akal) diartikan sebagai hal-hal yang berkaitan dengan budi dan akal manusia. Dalam bahasa Inggris, kebudayaan bersal dari kata culture, yang berasal dari kata latin colere, yaitu mengolah dan mengerjakan.Bisa diartikan juga sebagai mengolah tanah dan atau bertani. Kata culture kadang juga diterjemahkan sebagai "kultur" dalam bahasa Indonesia.Budaya adalah sistem makna dan keyakinan bersama yang dianut oleh para anggota organisasi yang menentukan cara mereka bertindak (Abdurrahman, 2013, p. 39).

Menurut Melvelle kebudayaan adalah segala sesuatu yang terdapat dalam masyarakat ditentukan oleh kebudayaan yang dimiliki oleh masyarakat itu sendiri. Istilah untuk pendapat itu adalah cultural-determinism. Herkovits memandang kebudayaan sebagai sesuatu yang turun temuran dari satu generasi kegenerasi yang lain, yang kemudian disebut sebagai Superorganic.Menurut Edward B. Taylor kebudayaan merupakan keseluruhan yang kompleks, yang didalamnya terkandung pengetahuan, kepercayaan,keseniaan, moral,hukum, adat istiadat dan kemampuan-kemampuan lain yang didapat seseorang sebagai anggota masyarakat.

\section{Pengertian Organisasi}

Organisasi berasal dari kata organon dalam bahasa Yunani yang berarti alat. Organisasi adalah suatu kelompok orang yang memiliki tujuan yang sama. Pengorganisasian atau organizing secara alamiah merupakan fase kedua setelah planning. Di samping secara faktual, dalam tataran syariah dari setiap sistem organisasi besar atau sekecil apapun. Dikatakan secara alamiah sebab fakta organizing tersebut secara logis ataupun faktual berlaku di manapun dan kapanpun walaupun dalam bentuk sederhana. Semua ini merupakan sistem penciptaan Allah Swt yang bersifat intangible (ada fakta sekalipun tidak bisa diraba). Seandainya terdapat organisasi yang tidak menjalankan fungsi organizing (sekalipun terdapat planning yang komprehensif) maka tidak akan pernah berjalan atau berhasil secara optimal melainkan hanya unsur kebetulan. Hal tersebut dapat diambil dari nash Al-Qur'an ataupun ketauladanan Rasulullah Saw dalam berperilaku. Secara nash, Allah swt berfirman dalam Al Qur'an surat Ash-Shaff (4): “Sesungguhnya Allah menyukai orang yang berperang dijalanNya dalam barisan yang teratur seakan-akan mereka seperti suatu bangunan yang tersusun kokoh."

Stephen P. Robbins seperti yang dikutip oleh Wiarawan memaknai organisasi sebagai "consciously coordinated social entity. With relatively continous basic to achieve a common goals or a set of a goals". Robbins mengemukakan bahwa organisasi merupakan social entity, unit-unit organisasi terdiri atas orang atau kelompok orang yang saling berinteraksi. Interaksi tersebut terkoordinasi secara sadar, artinya dikelola dalam upaya mencapai tujuannya. 
Menurut penulis organisasi adalah kumpulan satu orang atau lebih yang kemudian saling berinteraksi dan bekerja sama dalam rangka mencapai tujuan organisasi.

\section{Pengertian Umum Budaya Organisasi}

Budaya organisasi merupakan pola keyakinan dan nilai-nilai dalam organisasi yang dipahami, dijiwai dan dipraktekkan oleh anggota organisasinya sehingga pola tersebut memberikan makna tersendiri bagi organisasi yang bersangkutan dan menjadi dasar aturan berprilaku. Hal ini berarti setiap organisasi mempunyai sistem makna yang berbeda. Perbedaan ini menyebabkan setiap organisasi mempunyai karakteristik yang unik dan berbeda serta respon yang berbeda ketika menghadapi masalah yang sama. Di samping itu, perbedaan sistem makna ini dapat menyebabkan perbedaan prilaku para anggota organisasi dan prilaku organisasi itu sendiri. Akar perbedaan ini bersumber pada asumsi-asumsi dasar yang meliputi keyakinan, nilai-nilai, filosofi atau ideologi organisasi yang digunakan dalam memecahkan persoalan organisasi (Torang, 2014, p. 106).

Wiarawan mendefinisikan budaya organisasi sebagai nilai, norma-norma, asumsi, kepercayaan, filsafat, kebiasaan organisasi dan sebagainya (isi budaya organisasi) yang dikembangkan dalam kurun waktu lama oleh pendiri, pemimpin, dan anggota organisasi yang disosialisasikan dan diajarkan pada anggota baru serta diterapkan dalam aktivitas organisasi sehingga mempengaruhi pola pikir, sikap dan prilaku organisasi dalam memproduksi produk, melayani konsumen, dan mencapai tujuan organisasi.

Selanjutnya Wirawan mengemukakan beberapa pengertian budaya organisasi menurut pakar organisasi. Menurut Schein, budaya organisasi adalah pola asumsi dasar yang ditemukan atau dikembangkan oleh suatu kelompok orang selagi mereka belajar untuk menyelesaikan problem-problem, menyesuaikan diri dengan lingkungan eksternaldan berinteraksi dengan lingkungan internal. Menurut Schwartz dan Davis budaya Organisasi merupakan pola kepercayaan dan harapan yang dianut oleh anggota organisasi. Kepercayaan dan harapan tersebut menghasilkan nilai-nilai dengan kuat membentuk prilaku para individu dan kelompok-kelompok para anggota organisasi. Tunstall menyebut bahwa budaya Organisasi merupakan suatu konstelasi umum mengenai kepercayaan, kebiasaan, nilai, norma prilaku, dan cara melakukan bisnis yang unik bagi setiap organisasi yang mengatur pola aktivitas dan tindakan organisasi, serta melukiskan pola implisit, prilaku dan emosi yang muncul yang menjadi karakteristik dalam organisasi. Menurut Owen, bahwa budaya Organisasi adalah norma yang menginformasikan anggota organisasi mengenai apa yang dapat diterima dan apa yang dapat ditolak, nilai-nilai dominan yang dapat dihargai organisasi diatas yang lainnya, asumsi dasar dan kepercayaan yang dianut bersama organisasi, peraturan main yang harus dipelajari jika orang yang ingin sejalan dan dapat diterima sebagai anggota organisasi, dan filsafat yang mengarahkan dalam brhubungan dengan karyawan dan kliennya. 
Dari beberapa pengertian budaya organisasi diatas, penulis menyimpulkan bahwa Budaya Organisasi adalah sistem nilai yang dianut oleh keseluruhan anggota organisasi yang dapat dijadikan pedoman bagi karyawan untuk berprilaku dalam organisasi dan mengatasi masalah-masalah yang berkaitan dengan adaptasi eksternal dan integrasi internal. Budaya organisasi merupakan perwujudan sehari-hari dari nilai-nilai dan tradisi yang mendasari organisasi. Hal ini terlihat pada bagaimana para karyawan berprilaku, harapan karyawan terhadap organisasi dan sebaliknya, serta apa yang dianggap wajar dalam hal bagaimana karyawan melaksanakan pekerjaannya.

\section{Elemen Dasar Budaya}

Menurut Schein, seperti yang dikutif oleh James A. F Stooner at all dalam bukunya Management 1. Budaya ada dalam tiga tingkat, yaitu (Amir, 2017, p. 192) :

a. Artifact, adalah hal-hal yang "dilihat, didengar, diraba dan dirasa kalau seseorang berhubungan dengan sekelompok baru dengan budaya yang tidak dikenalnya”. Artifact termasuk produk, jasa dan bahkan tingkah laku anggota kelompok.

b. Espoused Value (Nilai-nilai yang didukung), adalah alasan yang diberikan oleh sebuah organisasi untuk mendukung caranya melakukan sesuatu.

c. Basic assumption (Asumsi dasar), adalah keyakinan yang dianggap sudah ada oleh anggota suatu organisasi.

\section{Tujuh Dimensi Budaya}

Riset mengemukakan bahwa ada tujuh dimensi yang secara keseluruhan menangkap hakikat budaya organisasi. Menilai organisasi dari ketujuh organisasi dimensi itu akan memberikan gambaran mengenai unsure-unsur pembentuk budaya organisasi, ketujuh organisasi tersebut yaitu(Tika, 2010, p. 10-11): Inovasi dan pengambilan resiko. Tingkat dimana para karyawan didorong untuk bersifat inovatif dan mengambil resiko; Perhatiaan pada detail. Tinkat dimana para karyawan diharapkan untuk menampilkan ketepatan, analisis dan perhatian terhadap detail; Orientasi hasil. Tingkat dimana para manajer memusatkan perhatian pada hasil-hasil bukannya pada teknik-teknik dan proses-proses yang digunakan untuk mencapai hasil-hasil itu; Orientasi manusia. Tingkat dimana kepuasan-kepuasan manajemen memperhitungkan pengaruh hasil-hasil terhadap manusia didalam organisasi itu; Orientasi tim. Tingkat dimana kegiatan-kegiatan kerja disusun sekitar tim-tim bukan individuindividu; Stabilitas. Tingkat dimana kegiatan-kegiatan organisasi menekankan usaha mempertahankan status bukan pertumbuhan. Dengan demikian, dapat disimpulkan bahwa dimensi budaya ada 3 yaitu : inisiatif, pengarahan dan pola komunikasi

3. Jenis-jenis Budaya Organisasi 
Deal dan Kennedy, seperti yang dikutip oleh wirawan mengemukakan bahwa budaya organisasi dapat dikelompokan menjadi empat jenis budaya yaitu:budaya keras/macho, budaya kerja/bermain keras, budaya pertaruhkan perusahaan anda dan budaya proses.

a. Budaya keras atau macho

Budaya ini ditandai oleh individu-individu yang terbiasa mengambil resiko tinggi dalam rangka mengharapkan keuntungan yang cepat tanda memikirkan mereka salah atau benar. Dalam budaya organisasi tipe ini kerja tim tidaklah penting, artinya nilai kerja sama tidak menjadi sesuatu yang dianggap penting dan tidak ada kesempatan untuk belajar dari kesalahan. Contoh dari perusahaan yang mengunakan budaya ini adalah industri hiburan.

b. Budaya kerja keras/bermain keras

Budaya organisasi ini memotivasi karyawan untuk mengambil resiko rendah dan mengharapkan pengembaliaan yang cepat. Budaya organisasi ini lebih mengutamakan pernjualan. Contoh perusahaan yang menggunakan budaya ini adalah real estate.

c. Budaya pertaruhkan perusahaan anda

Budaya ini ada lingkungan dimana resiko tinggi dan keputusan diambil sebelum hasil diketahui. Contoh perusahaan yang menerapkan budaya ini adalah pesawat terbang.

d. Budaya Proses

Budaya ini adalah budaya resiko rendah dengan pengambilan rendah; karyawan hanya focus kepada bagaimana sesuatu dilakukan dari pada hasil. Contoh perusahaan dengan menggunakan budaya ini adalah perusahaan perbankan.

\section{Norma dan Nilai dalam Organisasi}

\section{Pengertian Norma dan Nilai}

Norma dalah peraturan tatanan, ketentuan, standar, gaya dan pola prilaku yang menentukan prilaku yang dianggap pantas dan tidak dalam merespon sesuatu. Norma dalam organisasi mengatur prilaku organisasi. norma dalam organisasi tertuang dalam kode etik perusahaan. Kode etik (code of ethics) adalah pernyataan formal tertulis mengenai nilai-nilai, kepercayaan, filsafat organisasi, apa yang diharapkan dan apa yang dihindari, serta apa yang dilarang dilakukan oleh anggota organisasi (Wirawan, 2017, p. 47).Sedangkan nilai adalah suatu kepercayaan permanen mengenai apa yang tepat dan tidak tepat yang mengarahkan tindakan dan prilaku seseorang.

\section{Nilai-Nilai dalam Organisasi}

\section{a. Nilai Organisasi (Value Of Organization)}

Nilai dalam organisasi menjadi pedoman perilaku anggota organisasi dalam mencapai suatu tujuan bersama. Nilai organisasi ini tertuang dalam visi dan misi. Visi adalah 
pernyataan mengenai organisasi akan apa atau suatu keyakinan akan suatu kondisi mendatang. Sedangkan misi adalah gambaran apa yang akan dilakukan organisasi untuk mencapai visi. Jika proses implementasi visi dan misi terlaksana dengan baik maka organisasi akan sukses besar.

\section{b. Nilai Karyawan (Value Of Employee)}

Di samping nilai organisasi, ada juga nilai karyawan. Nilai karyawan adalah suatu kepercayaan permanen mengenai apa yang tepat dan tidak tepat mengarahkan tindakan dan perilaku karyawan terhadap organisasi atau sesuatu yang dianggap penting oleh karyawan. Pada saat karyawan memasuki organisasi, mereka datang dengan kepentingan khusus atau yang sering disebut dengan nilai-nilai pribadi. Karyawan menyumbangkan tenaga, keahlian dengan mengharapkan suatu imbalan berupa materi atau kepuasan batin, yang kemudian menjadi suatu nilai bagi karyawan.

\section{c. Nilai Religi (Value Of Religion)}

Dalam perbankan syariah ada nilai religi (value of religion). Subtansi dalam nilai religi adalah nilai-nilai keimanan dan ketauhidan. Eksistensi dalam nilai-nilai religi ini sangat penting dalam bank syariah. Nilai religi inilah yang membedakan identitas Bank Syariah dengan Bank Konvensional. Ketika bank syariah dilandasi dengan nilai-nilai ketauhidan maka diharapkan bank syariah akan terhindar dari unsur-unsur gharar,maysir dan riba karena menyadari ada pengawasan dari Allah swt.

\section{Proses Integrasi Nilai}

Ketika nilai organisasi nilai-nilai karyawan dan nilai-nilai religi terintegrasi dengan baik maka akan tercipta nilai-nilai dianut bersama dan tercipta kesamaan tujuan dalam organisasi.kemudian lahirlah organisasi (Wirawan, 2017, p. 48)

Gambar 2.1

Skema Integrasi Nilai

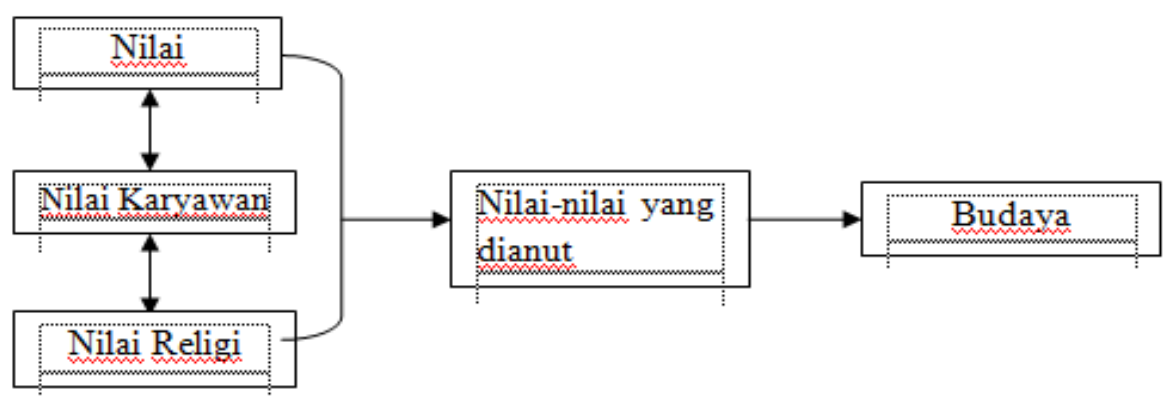




\section{Pengertian Kinerja Karyawan}

Istilah kinerja berasal dari kata job performance atau actual performance(prestasi kerja atau prestasi sesungguhnya yang dicapai oleh seseorang). Pengertian kinerja (prestasi kerja) adalah hasil kerja secara kualitas dan kuantitas yang dicapai oleh seorang pegawai dalam melaksanakan tugasnya sesuai taggung jawab yang diberikan kepadanya(Mangkunegara, 2011, p. 67).

\section{Faktor-Faktor yang mempengaruhi Kinerja}

Faktor yang mempengaruhi pencapaian kinerja adalah factor kemampuan (ability) dan factor motivasi (motivation) (Mangkunegara, 2011, p. 68)

\section{a. Faktor Kemampuan}

Secara psikologis, kemampuan (ability) pegawai terdiri dari kemampuan potensi (IQ) dan kemampuan reality (knowledge + skill). Artinya, pegawai yang memiliki IQ diatas ratarata (IQ 110-120) dengan pendidikan yang memadai untuk jabatanya dan terampil dalam mengerjakan pekerjaan sehari-hari,maka ia akan lebih mudah mencapai kinerja yang diharapkan. Oleh karena itu, pegawai perlu ditempatkan pada pekerjaan yang sesuai dengan keahliannya (the right man in the right place, the right man on the riht job).

\section{b. Faktor Motivasi}

Motivasi terbentuk dari sikap (attitude) seorang pegawai dalam menghadapi situasi (situasion) kerja. Motivasi merupakan kondisi yang menggerakan diri pegawai yang terarah untuk mencapai tujuan organisasi (tujuan kerja).Sikap mental merupakan kondisi mental yang mendorong diri pegawai untuk berusaha mencapai prestasi kerja secara maksimal.Sikap mental seorang pegawai harus sikap mental yang siap secara psikofisik (siap secara mental, fisik, tujuan dan situasi). Artinya, seorang pegawai harus siap mental, mampu secara fisik, memahami tujuan utama dan target kerja yang akan dicapai, mampu memanfaatkan dan menciptakan situasi kerja.

\section{Manfaat Penilaian Kerja}

Beberapa tujuan penilaian kerja :

a. Penilaian kerja untuk tujuan administrasi personalia, karena hasil penilaian kerja pegawai menjadi dasar untuk :

1) Penetapan naik turunya penghasilan pegawai,

2) Penetapan kepesertaan pelatihan pegawai, 
3) Penetapan jenjang karir,jabatan pegawai dalam wujudnya sebagai promosi, rotasi atau demosi jabatan.

b. Sebagai dasar untuk mengevaluasi kinerja dan produktivitas organisasi dan unit kerja pada umumnya serta individu-individu pegawai dalam setiap jabatan khususnya

c. Untuk pengembangan diri pegawai yang meliputi :

1) Sebagai dasar untuk mengidentifikasi kekurangan atau kelebihan karyawan sehingga dapat menjadi salah satu bahan pertimbangan dalam melibatkan pegawai dalam pengembangan program-program pegawai.

2) Sebagai alat untuk mendorong atau membiasakan para atasan atau pejabat penilai dalam mengamati prilaku kerja pegawai secara keseluruhan sehingga diketahui minat-minat, kemampuan-kemampuan serta kebutuhan-kebutuhan pegawai.

Tidak hanya teori dari kalangan ahli manajemen, ratusan tahun yang lalu, Rosulullah SAW sudah mengigatkan akan pentingnya melihat hasil kerja atau amal sesorang. Hal ini dibuktikan dengan sebuah hadis dari Imam Ahmad, dari Anas Ibn Malik ra., menyebutkan bahwa Rosulullah SAW bersabda: "Kalian tidak perlu merasa takjub (bangga) atas seseorang himgga kamu melihat sesuatu yang dihasilkannya."

Jelas sekali bahwa ungkapan "hingga kamu melihat sesuatu yang dihasilkannya" merujuk pada kinerja, hasil kerja seseorang yang penting untuk dinilai supaya hasilnya memuaskan.

Metode Penilaian Kerja

Terdapat banyak bentuk metode penilaian dan pada dasarnya dapat dikelompokan menjadi dua, yaitu :

a. Metode tradisional, yaitu metode yang paling sederhana dan tertua yang dapat diterapkan baik secara sistematis maupun tidak sistematis. Yang termasuk metode ini adalah :

1) Rating scale, suatu penilaian yang diakukan oleh atasan atau suvervisor untuk mengukur karakteristik. Seperti : inisiatif, ketergantungan, kematangan dan kontribusinya terhadap tujuan kerjanya.

2) Employee Comparation, suatu metode penilaian yang dilakukan dengan cara membandingankan seorang karyawan dengan karyawan lainnya.

3) Check List, dengan metode ini penilaian tinggal memilih kalimat-kalimat atau kata-kata yang mengambarkan prestasi kerja dan karakteristik setiap karyawan, baru melaporkannya kebagian personalia untuk menetapkan bobot nilai, indeks nilai dan kebijaksanaan selanjutnya bagi karyawan yang bersangkutan.

4) Freedom Essay, dalam metode ini penilaian diharuskan membuat karangan yang berkenaan dengan karyawan yang sedang dinilainya. 
5) Critical Incident, dalam metode ini penilaian harus mencatat semua kejadian mengenai tingkah laku bawahannya sehari-hari kemudian dimasukan kedalam buku catatan khusus yang terdiri dari tingkah laku bawahannya.

b. Metode Modern, yaitu suatu metode penilaian karyawan yang merupakan pengembangan dari metode tradisional sebelumnya. Yang termasuk metode ini adalah:

1) Assesment centre, dalam metode ini biasanya dibentuk tim penilaian khusus, yang berasal dari luar, dari dalam, maupun kombinasi semuanya.

2) Management by objective (MBO), dalam metode ini karyawan langsung diikut sertakan dalam perumusan pemutusan persoalan dengan memperhatikan kemampuan bawahan dalam menentukan sasaran masing-masing yang ditekankan pada pencapaian sasaran perusahaan.

3) Human asset accounting. Dalam metode ini karyawan dinilai sebagai individu modal jangka panjang, sehingga sumber tenaga kerja dinilai dengan cara membandingkan terhadap variabel-variabel yang dapat mempengaruhi keberhasilan perusahaan.

\section{Penggunaan Hasil Penilaian Kerja}

Hasil penilaian kerja digunakan untuk mengambil kebijakan yang berkenaan dengan tiga hal, yaitu (Hasibuan, 2017, p. 58):

\section{a. Mutasi}

Melayu Hasibuan S.P mendefinisikan mutasi seperti yang dikutip oleh Suhendra dan Murdiyah Hayati sebagai suatu perubahan posisi/jabatan/tempat/pekerjaan yang dilakukan baik secara horizontal maupun vertical (promosi dan demosi) di dalam satu organisasi yang pada dasarnya merupakan salah satu fungsi pengembangan karyawan, karena tujuannya adalah meningkatkan efisiensi dan efektifitas kerja perusahaan tersebut.

\section{b. Promosi}

Promosi adalah mutasi yang memperbesar kewenangan dan tanggung jawab karyawan kejabatan lain.

\section{c. Demosi}

Demosi adalah suatu perpindahan karyawan dalam suatu organisasi dari satu posisi ke posisi lain yang lebih rendah baik posisi, jabatan, maupun kewenangannya, dan juga melibatkan penurunan status maupun gajinya. Demosi biasanya digunakan untuk menghindari ketidak tepatan penempatan karyawan. 


\section{METODE}

Jenis penelitian yang digunakan penulis adalah penelitian kuantitatif, penelitian yang informasi atau data dianalisis menggunakan statistic, mulai dari pengumpulan data, validasi dan sebagainya (Kountur, 2007, p. 7). Subjek penelitian ini adalah seluruh pegawai Bank Jabar Banten KCP Ciawi dan studi penelitian ini menggunakan pendekatan sensus.

\section{HASIL DAN PEMBAHASAN}

Dari landasan teori dan hasil data lapangan yang telah peneliti jabarkan, maka langkah selanjutnya adalah melakukan penganalisisan terhadap data-data tersebut, sehingga hasilnya dapat diketahui secara transparan. Mengingat data-data yang terkumpul bersifat kuantitatif, maka dalam menganalisa data digunakan analisis deskriptif dengan menggambarkan dan mengkomparasikan dengan konsep manajemen sarana dan prasarana yang tersedia.

\section{Budaya Organisasi Pada PT.Bank Jabar Banten Syariah KCP Ciawi}

Budaya perusahaan memberikan dampak bagi pertumbuhan kinerja karyawan karena pada dasarnya membangun suasana kerja yang nyaman diperlukan pedoman prilaku yang ditanamkan sejak bergabung jadi pegawai baru. Pelatihan pedoman perilaku dapat menjadi awal bagi karyawan untuk membentuk karakter individu agar lebih baik dalam bekerja dan mampu bersosialisasi baik dalam sesama karyawan, dengan atasan maupun dengan nasabah, sehingga terlihat tujuan penerapan budaya perusahaan adalah agar seluruh individu dalam perusahaan mematuhi dan berpedoman pada sistem nilai dan norma-norma yang berlaku dalam perusahaan tersebut.

Dari hasil penelitian yang telah peneliti lakukan, adapun budaya perusahaan di bank BJB Syariah KCP Ciawi yaitu MASLAHAH. Maslahah yaitu sesuatu yang mendatangkan kebaikan, manfaat, faedah atau kegunaan. Selanjutnya kata maslahah tersebut diuraikan menjadi butir-butir nilai. Berikut ini butir-butir budaya perusahaan Bank BJB Syariah KCP Ciawi sebagai berikut :

\section{a. Militan}

Membangkitkan semangat dan berdedikasi tinggi, penuh pengabdian, tidak kenal lelah, mengeluarkan kemampuan terbaik dalam mendukung dan mewujudkan visi misi perusahaan(BJBS, 2015). Sesuai dengan firman Allah Swt, dalam al-Quran surah Al-Insyirah ayat 7 yakni :

Artinya : "Maka apabila kamu telah selesai dari suatu pekerjaan maka kerjakanlah urusan yang lain dengan sungguh-sungguh”. (QS, Al-insyirah 7).

Bekerja keras disertai dengan niat yang sungguh-sungguh insyaah keinginan kita dapat terkabul. Orang yang terbiasa hidup bekerja keras mereka selalu bekerja menyelesaikan 
masalah yang belum tuntas. Pekerja keras juga orang yang pandai membagi waktu. Salah satu orang modern adalah mereka yang menyikapi waktu dengan bersungguh-sungguh. Seorang yang memiliki etos kerja sadar betul bahwa kehadiran dirinya di muka bumi bukanlah sekedar untuk "being" melainkan ada semangat mengelora diseluruh pori-pori tubuhnya untuk mengisi waktu menuju kepada tingkatan becoming dan akhirnya memperoleh nilai di sisi Allah, menjadi bagian dari khairu ummah(Tasmara, 2002, p. 78).

b. Amanah

Sifat mental yang didalamnya terkandung unsur kepatuhan terhadapa hukum, tanggung jawab terhadap tugas, kesetian terhadap komitmen, keteguhan dalam memegang janji dan mempunyai integritas(BJBS, 2015). Sesuai dengan firman Allah SWT, dalam al-Quran surah Al-jumu'ah: 9-10, yakni :

Wahai orang-orang yang beriman, apabila kalian diseru untuk menunaikan shalat jum'at, maka bersegeralah untuk mengingat Allah dan tinggalkanlah jual beli. Yang demikian itu lebih baik bagi kalian jika kalian mengetahui. Apabila telah ditunaikan shalat, maka bertebaranlah kalian dimuka bumi, dan carilah karunia Allah, dan ingatlah Allah banyak-banyak supaya kalian beruntung. "(QS Al-jumuah : 9-10)

Disiplin adalah kebiasaan, setiap tindakan yang berulang pada waktu dan tempat yang sama. Kebiasaan positif yang harus dipupuk dan terus ditingkatkan dari waktu ke waktu. Pribadi yang disiplin sangat berhati-hati dalam mengelola pekerjaan serta penuh tanggung jawab memenuhi kewajibannya (BJBS, 2015).

\section{c. Solusi}

Kemampuan untuk memberikan jalan keluar, penyelesaian, dan pemecahan masalah, seta mampu beradaptasi terhadap perubahan, rintanga, dan tantangan. Situasi dan kondisi apapun untuk tercapainya visi dan misi perusahaan.Sesuai dengan firman Allah Swt dalam surat Ar-Rad (11): "Sesungguhna Allah tidak akan mengubah nasib suatu kaum hingga mereka mengubah diri mereka sendiri".

Ibaratkan kapal, kapal yang baik bukanlah kapal yang hanya terlambat dipelabuhan, melainkan kapal yang mampu mengarungi samudera dan samapai ketempat tujuan. Mereka melihat tantangan bukan sebagi hambatan atau kendala, melainkan sebuah persyaratan untuk mencapai kemuliaan (BJBS, 2015).

\section{d. Layanan}

Memiliki daya tarik, menyenangkan dalam berprilaku baik kenasabah dalam memberikan pelayanan yang terbaik sesuai atau melebihi harapan nasabah sehingga mereka merasa sangat puas(BJBS, 2015).Sesuai dengan firman Allah Swt dalam surat QS. AlQhashas (77): "Dan carilah apa yang telah dianugrahkan Allah kepadamu (kebahagian) 
negri akhirat. Dan janganlah kamu melupakan kebahagian dari (kenikmatan) duniawi dan berbuat baiklah (kepada orang lain) sebagaimana Allah telah berbuat baik kepadamu, dan janganlah kamu berbuat kerusakan di (muka) bumi. Sesungguhnya Allah tidak menyukai orang-orang yang berbuat kerusakan".

Melayani atau menolong seseorang merupakan bentuk kesadaran dan kepedulian terhadap nilai kemanusiaan. Member pelayanan dan pertolongan merupakan investasi yang kelak akan dipetik keuntungannya, tidak hanya diakhirat tetapi di dunia pun mereka sudah merasakannya. Sebagaimana teladan Rosulullah Saw, seperti yang dimuliakannya tamu yang datang kepadannya(Tasmara, 2002, p. 96).

\section{e. Harmoni}

Keselarasan, kombinasi antar bagian, kekeluargaan dan menjaga silaturrahmi(BJBS, 2015).Sesuai dengan firman Allah Swt dalam surat An-Nisa (1):"Hai sekalian manusia bertakwalah kepada Tuhan-mu yang telah menciptakan kamu dari seorang diri, dan dari padanya Allah menciptakan istrinya ; dan dari pada keduanya Allah memperkembang biakan laki-laki dan perempuan yang banyak. Dan bertakwalah kepada Allah yang dengan (mempergunakan) nama-Nya kamu saling meminta satu-sama lain, dan (peliharalah) hubungan silaturahmi, sesungguhnya Allah telah menjaga dan mengawasi kamu”.

Silaturrahmi mempunyai tiga sisi yang sangat menguntungkan. Pertama, memberikan nilai ibadah. Kedua, apabila dilakukan dengan kualitas akhlak yang mulia akan memberikan impresi bagi orang lain sehingga dikenang, dicatat, dan dibicarakan banyak orang (mungkin ini pula yang disebut panjang umur). Ketiga, bahwa silaturrahmi dapat memberikan satu alur informasi yang memberikan peluang dan kesempatan usaha(Tasmara, 2002, p. 133).

\section{f. Holistik}

Cara pandang yang menyatakan bahwa keseluruhan sebagai satu kesatuan lebih penting dari pada bagian-bagiannya karena kekeuatan ada pada kebersamaan.Sesuai dengan firman Allah SWT, dalam surah QS. As-Shaf(4): "Sesungguhnya Allah menyukai orang yang berperang dijalan-Nya dalam barisan yang teratur seakan-akan mereka seperti suatu bangunan yang tersusun kokoh". Pelaksanaan nilai-nilai MASLAHAH tersebut yaitu seperti yang disampaikan oleh Bapak Asep Irfan selaku Customer Service di Bank BJB KCP Ciawi.“pelaksanaan nilai-niali budya perusahaan cukup baik dan selalu diterapkan oleh semua karyawan"(Irfan, 2018).Suatu organisasi yang baik harus mampu menciptakan budaya organisasi yang baik dan benar agar dapat dijiwai dan diperaktekan oleh karyawan dalam menjalankan tugas. Budaya organisasi yang berhubungan langsung dengan karyawan penulis menyimpulkan ada tiga indikator yang berhubungan dengan budaya organisasi di Bank BJB Syariah KCP Ciawi yaitu pengarahan, sistem imbalan, dan pola komunikasi. Dari ketiga indikator tersebut rata-rata responden menjawab setuju dengan presentase 41-52\%. Jadi dapat 
disimpulkan bahwa budaya organisasi di bank BJB Syariah KCP Ciawi cukup baik, hanya saja menurut salah satu karyawan di BJB Syariah KCP Ciawi beliau mengatakan bahwa susahnya mengubah mind set pegawai lama yang sudah merasa nyaman dengan nilai dan prilaku yang sudah ada sebelumnya tapinsemua itu masih bisa diatasi(Irfan, 2018).

\section{Kinerja Karyawan Bank BJB Syariah KCP Ciawi}

Kinerja adalah hasil kerja yang dapat dicapai oleh seseorang atau sekelompok orang dalam suatu organisasi dalam rangka mencapai tujuan organisasi pada priode waktu tertentu. Keberhasilan suatu organisasi tertentu. Keberhasilan sebuah organisasi adalah ketika kinerja para pegawainya sudah mencapai tinngkat maksimal.Hal ini menunjukan bahwa kinerja karyawan di Bank BJB Syariah dapat dikatakan baik sesuai dengan jawaban yang diberikan oleh responden. Kinerja karyawan pada Bank Bjb Syariah KCP Ciawi dapat diukur melalui indicator kedisiplinan, kerjasama dan prestasi kerja. Dimana jawaban dari semua responden menjwab setuju dengan presentase 35-52\%, dapat dibuktikan menurut salah satu staf bank BJB Syariah KCP Ciawi bahwa sebagian besar karyawan selalu berusaha untuk melaksanakan pekerjaan dengan baik dan berusaha mencapai target yang telah ditetapkan(Irfan, 2018).Namun selain di ukur dari ketiga indikator tersebut ketika penulis melakukan wawancara dari salah satu staf BJB Syariah KCP Ciawi dalam hal kerja sama, sebagian kecil karyawan individual dan kuarang mampu untuk bersosalisasi. Selanjutnya bisa dilihat kinerja Bank BJB Syariah KCP Ciawi dari kinerja keuangan perusahaan yaitu dari beberapa rasio diantaranya rasio solvabilitas, profitabilitas dan likuiditas. Dari rasio-rasio tersebut dapat dikatakan keuangan Bank BJB Syariah cukup baik dibuktikan dengan rasio likuiditas pada tahun 2017 NPF mengalami penurunan, dimana kredit macetnya bank tersebut semakin sedikit jadi bank BJB Syariah Ciawi dapat dikatakan sehat.

\section{Pengaruh Budaya Organisasi Terhadap Kinrja Karyawan di Bank BJB Syariah KCP Ciawi}

Budaya organisasi tentu berpengaruh pada kinerja karyawan Bank BJB Syariah KCP Ciawi karena budaya organisasi bank bjb Syariah yang disebut Maslahah didalamnya terdapat nilai-nilai yang berfaidah dan bermanfaaat bagi karyawan yang menjalankannya dan nilainilai tersebut dijadikan pedoman dalam bertindak untuk melakukan sebuah kegiatan perusahaan. Termasuk hal-hal yang ingin dicapai sesuai dengan visi, misi perusahaan akan berjalan secara efisien dan efektif yakni dengan adanya karyawan yang melaksanakan/menerapkan nilai-nilai budaya terebut maka perusahaan akan berjalan dengan baik.Hasil penelitian melalui analisis regresi sederhana menunjukan bahwa budaya organisasi sangat berpengaruh terhadap kinerja karyawan hal ini dapat dilihat dari persamaan hasil regresi berikut :

$$
\mathrm{Y}=5,176+1,073 \mathrm{X}
$$


Dimana $\mathrm{Y}$ adalah kinerja karyawan, sedangkan $\mathrm{X}$ adalah budaya organisasi.dari persamaan diatas dapt ditarik kesimpulan, yakni :

a) Bila ada persamaan 1 unit dari kinerja karyawan maka aka nada meningkat budaya organisasi sebesar 1,073

b) Koefisien regresi $\mathrm{b}=1,073$ mengindikasikan besaran penambahan kinerja karyawan untuk setiap pertambahan budaya organisasi.

Dari hasil perhitungan Regresi sederhana tersebut diperoleh nilai signifikansi sebesar 0,000 dan nilai $\alpha$ sebesar 0,025 karena pengujian dilakukan dua sisi maka nilai $\alpha$ tersebut dibagi 2, sehingga nilai $\alpha=0,05 / 2=0,025$ oleh karena itu dapat dibandingkan denga nilai signifikan $0,000<0,025$ maka berdasarkan kaidah pengujian maka Ho ditolak Ha di terima artinya ada pengaruh antara budaya organisasi $(\mathrm{X})$ terhadap kinerja karyawan $(\mathrm{Y})$.

Dari hasil penelitian dapat disimpulkan bahwa kinerja karyawan dipengaruhi oleh budaya organisasi sebesar 0,883 . Yang artinya kinerja karyawan dipenaguhi oleh budaya organisasi sebesar $88,3 \%$ dan sisanya $11,7 \%$ dipengaruhi oleh faktor lain yang tidak diteliti peneliti.

\section{SIMPULAN}

1. Penerapan budaya organisasi pada Bank BJB Syariah KCP Ciawi sudah baik. Hal ini terbukti, karena nilai rata-rata dari keseluruhan pernyataan responden dengan tiga indikator yaitu inisiatif, pengarahan dan pola komunikasi adalah sebesar 3.45 yang berada pada interval 3.40- 4.19. hal ini terlihat pada karyawan selalu memilah-milah suatu pekerjaan mana yang perlu didahulukan supaya dapat terselesaikan seluruhnya. Walau demikian dorongan dari perusahaan kepada pegawai untuk mencapai produktivitas maksimal dianggap masih kurang efektif.

2. Kinerja karyawan pada Bank BJB Syariah KCP Ciawi dapat dikatakan baik. Hal ini terbukti, dari nilai rata-rata keseluruhan pernyataan responden dengan tiga indikator yaitu kedisiplinan, kerjasama, dan prestasi kerja karena nilai rata-rata dari keselurahan pernyataan adalah 3.50 yang berada pada interval 3.40 - 4.19. Dimana karyawan selalu berusaha untuk melaksanakan pekerjaan dengan baik dan berusaha mencapai target yang telah di tetapkan. Namun, dalam hal kemandirian dan bersosialisasi sebagian kecil karyawan karyawan kurang mampu dengan cepat menyesuaikan dan belajar secara mandiri terhadap pekerjaan yang menjadi tanggung jawabnya.

3. Pengaruh budaya organisasi pada kinerja karyawan pada Bank BJB Syariah KCP Ciawi berdasarkan hasil perhitungan Regresi sederhana tersebut diperoleh nilai signifikansi sebesar 0,000 dan nilai $\alpha$ sebesar 0,025 karena pengujian dilakukan dua sisi maka nilai $\alpha$ tersebut dibagi 2 , sehingga nilai $\alpha=0,05 / 2=0,025$ oleh karena itu dapat dibandingkan 
dengan nilai signifikan $0,000<0,025$ maka berdasarkan kaidah pengujian maka Ho ditolak Ha di terima artinya ada pengaruh antara budaya organisasi (X) terhadap kinerja karyawan (Y).

Dari hasil penelitian dapat disimpulkan bahwa kinerja karyawan dipengaruhi oleh budaya organisasi sebesar 0,883. Yang artinya kinerja karyawan dipengaruhi oleh budaya organisasi sebesar $88,3 \%$ dan sisanya $11,7 \%$ dipengaruhi oleh faktor lain yang tidak diteliti.

\section{REFERENSI}

Abdurrahman, N. H. (2013). Manajemen Bisnis Syariah \& Kewirausahaan. Bandung: Pustaka Setia.

Amir, M. T. (2017). Perilaku Organisasi. Jakarta: PT Fajar Interpratama Mandiri.

BJBS. (2015). Buku Saku Karyawan Bank BJB Syariah KCP Ciawi. Direksi Bank Jabar: Bandung.

Handoko, T. H. (2008). Manajemen Personalia \& Sumber Daya Manusia. Yogyakarta: BPFE-Yogyakarta.

Hasibuan, M. (2017). Manajemen Sumber Daya Manusia. Jakarta: PT. Bumi Aksara.

Irfan, A. (2018, February 12). Menurunnya kinerja karyawan yang terlihat dari penurunan kinerja perusahaan.

Kountur, R. (2007). Metode Penelitian Untuk Penulisan Skripsi dan Tesis. Jakarta: PPM.

Lidiawati, L. (2008). Pengaruh Budaya Organisasi Terhadap Kinerja Karyawan. Universitas Widyatama.

Mangkunegara, A. P. (2011). Manajemen Sumber Daya Manusia Perusahaan. Bandung: PT. Remaja Rosda Karya.

Nurjanah. (2008). Analisis Budaya Organisasi Dan Pengarunya Terhadap Kinerja Karyawan. UIN Syarif Hidayatullah.

Tahun 2014 Bank BJB Syariah mengembangkan suatu budaya organisasi baru yang disebut Maslahah. (n.d.). Retrieved from www.bank bjbsyariah.co.id

Tasmara, T. (2002). Membudayakan Etos Kerja Islami. Jakarta: Gema Insani Press.

Tika, Moh. P. (2010). Budaya Organisasi dan Peningkatan Kinerja. Jakarta: Salemba. 
Jurnal Ekonomi Syariah Vol. 5. No. 1. Mei 2020

p-ISSN 2548-5032 e-ISSN 2714-769X

Torang, S. (2014). Organisasi dan Manajemen. Bandung: Alfabeta.

Wirawan. (2017). Budaya dan Iklim Organisasi Teori dan Apliksi Penelitian. Jakarta: Salemba Empat. 